\title{
Sero-Prevalence Study of Camel Trypanosomiasis in Selected Villages of Galkayo, Somalia
}

\author{
Abdulgani Huruse Ismail Mohamoud \\ Faculty of Veterinary Medicine, Red Sea University, Galkayo, Somalia \\ Email: huruse122@gmail.com
}

How to cite this paper: Mohamoud, A.H.I. (2017) Sero-Prevalence Study of Camel Trypanosomiasis in Selected Villages of Galkayo, Somalia. Open Journal of Veterinary Medicine, 7, 31-37. https://doi.org/10.4236/ojvm.2017.74004

Received: March 5, 2017

Accepted: April 16, 2017

Published: April 19, 2017

Copyright $\odot 2017$ by author and Scientific Research Publishing Inc. This work is licensed under the Creative Commons Attribution International License (CC BY 4.0).

http://creativecommons.org/licenses/by/4.0/ (c) (i) Open Access

\begin{abstract}
A cross-sectional study was carried out aimed to estimate sero-prevalence of camel trypanosomiasis and to investigate the related risk factors of the disease in Four Selected Villages of Galkayo, Mudug region from $14^{\text {th }}$ March 2016 up to $20^{\text {th }}$ April 2016. Blood samples were collected from 69 randomly selected camels of the four study villages, and samples were allowed to clot at room temper to detect the sero-prevalence of trypanosome using Card Agglutination Test for Trypanosomiasis (CATT). The results indicated that the overall sero-prevalence of trypanosomiasis in camels that $15.9 \%$ (11) samples were positive for trypanosome evansi ( $T$. evansi) was recorded. Higher infection was found in female (19.4) as compared to male (11.1), However, there is no statistically significant difference in sero-prevalence between sex categories $(\mathrm{P}>0.05)$. High Test infection of sero-prevalence was noted $20 \%$ in young age $(<10)$ followed by $19 \%$ in adult age group $(>10)$, and there was statistically significant difference $(\mathrm{P}<0.05)$ in susceptibility among age groups. These results seem to indicate that $T$. evansi infection is high in the study area. There is need of further control of camel trypanosomiasis through the uses of curative and prophylactic drugs to avoid the various problems.
\end{abstract}

\section{Keywords}

Sero-Prevalence, Trypanosomiasis, CATT, Camel, Galkayo, Somalia

\section{Introduction}

The Camel is the most capable animal species which survive and produce under harsh environmental conditions.

The one-humped camel (Camelus dromedarius) is the most domestic animals in Somalia, which is mostly found in rid and semi-rid area, and the commonest 
uses of camel in Somalia are milk, meat production and viber (such as hide and wool); in addition, mature male camel plays important role for transport water, nomadic household migration and other utensils [1].

Camel is also used in social rituals, while marriage without giving camel to the new father-in-law is unusual in Somalia. However, camels are only animals used to determine to the victim such as blood compensation and homicide [2].

Camel trypanosomiasis is parasitic disease that causes serious economic losses in livestock from anemia, loss of condition, anorexia, weakness, and emaciation that lead to low milk production and meat yield, increase of abortion and death [3].

Trypanosomiasis is a complex disease caused by protozoan parasitic in the family Trypanosomatidae which is found in blood [4].

The disease is caused by flagellate protozoan parasitic called trypanosomes; most trypanosomes are transmitted by tsetse flies [5].

Trypanosoma evansi is transmitted from animal to animal mechanically (noncyclically) by biting flies, including Tabanus spp., Stomaxys spp. and Musca spare vectors although Vampire bats in South and Central America are hosts, reservoirs and vectors of $T$. evansi; they transmit $T$. evansi mechanically in their saliva, and may develop high parasitaemia which may kill the bat. Recovered bats serve as carriers [6].

\section{Materials and Methods}

\subsection{Study Area}

The Federal Republic of Somalia is a country located in the Horn of Africa, it is covered an area of 638,000 square kilometers.

Land-mass is dominated by arid and semiarid rangelands for which pastoralism is the most appropriate form of Land use.

Galkayo is the one of the largest and oldest city in central regions of Somalia; it is capital of mudug region, connecting the northern and southern halves of east Africa country. It was formally established 1901.

The average annual temperature ranges between $33.9^{\circ} \mathrm{C}-28.7^{\circ} \mathrm{C}$, the altitude is $47^{\circ} \mathrm{N}-26^{\circ} \mathrm{N}$ and longitude $6^{\circ} \mathrm{E}-45^{\circ} \mathrm{E}$ in the time zone of East of Africa, The average humidity is about $50 \%$ [7].

The Rainfall is variable and sparse with no one area receiving more than 400 $\mathrm{mm}$ of rain annually. Therefore, nomads rely primarily on wells as a water source rather than surface water [8].

The study was conducted from $14^{\text {th }}$ march 2016 up to $20^{\text {th }}$ April 2016 at four villages were Halbookhad, Godad, Talacad and Tawakal, which was located in north Galkaio District.

\subsection{Study Animal}

A total of 69 indigenous breeds of camels (one hump camel) of different ages and sexes (27 male and 42 female), reared under open system were used to determine the sero-prevalence of Trypanosomiasis. 


\subsection{Study Design and Sample Size}

Across-sectional was conducted to determine the sero-prevalence of camel Trypanosomiasis by selecting site of villages in purposively as suitable. The study camels were selected by using simple random sampling method by taking age, sex and body condition into count [9].

Sample size was calculated using Thrusfield (1995) formula.

$$
N=4 P Q / L^{2}
$$

where $N$ is the require sample size, $P \exp$ was the expected prevalence and $\mathrm{d}$ is the desired about precision and $L$ allowable error.

\subsection{Blood Sample Collection}

A total of 69 camels Whole blood samples were collected from jugular vein by puncture using plain vacutainers tubes and allowed to clot overnight at room temperature. Serum was separated from clotted blood by transferring to other tube, and transported immediately to the Galkaio Central veterinary laboratory for processing.

\subsection{Sample Examination Procedure: Serological Testing}

Card Agglutination Test for Trypanosomiasis (CATT) for T. evansi is a direct and rapid agglutination test used for detection of Trypanosome evansi. Serum samples were diluted up to 1:4 with buffer. Then $25 \mu$ of diluted serum was pipetted on to a plastic coated test card, and added with one drop of CATT reagent, the reaction mixture was spread out gently by using a clean stirring rod and allowed to react on the card with help of manual rotation for 5 minutes. Blue granular agglutinations indicate a positive reaction visible to the naked eye and also we used blood staining.

\subsection{Statistical Analysis}

Collected data were entered, coded and kept in a Microsoft ${ }^{\circledR}$ Excel spread sheet for Windows ${ }^{\circledR} 2007$ data base before removed to SPSS sheet. The Statistical Package for Social Sciences (SPSS) for Windows ${ }^{\circledR}$ version 20 was used for all suitable statistical analysis.

\section{Results}

In this study the total of 69 blood samples collected in villages (Halbookhad, Godad and Tawakal, Talacad) and examined 11 (15.9) samples was sero-positive for T. evansi.

The Highest trypanosome infection was recorded in Tawakal followed by Talacad Godad with the lowest sero-prevalence was recorded Halabookhad and Godad villages as showed in Table 1.

Considering the sex of examined camels as indicated in Table 2, 3 (4.3\%) of males and $8(11.6 \%)$ of females out of 69 examined camels were sero-positive for Trypanosomiasis. 
The Highest rate of trypanosome infection (10.1\%) was noted in age of $>10$ years and followed by $(5.8 \%)$ in $<10$ years, there was statistically difference in sero-prevalence between ages as delineated in Table 3.

Depending on body conditions, $(76.8 \%)$ poor and $(23.2 \%)$ medium was recorded is showed in Table 4.

\section{Discussion}

The present study suggests that from 69 samples randomly selected camels in

Table 1. Sero-prevalence of camel Trypanomiasis on the basis of selected villages.

\begin{tabular}{ccccccc}
\hline & & \multicolumn{2}{c}{ Results } & Total & $\begin{array}{c}\text { Sero-Prevalence } \\
(\%)\end{array}$ \\
\cline { 3 - 5 } & & Negative & Positive & & 11.6 \\
\hline \multirow{3}{*}{ Origin of animal } & Halabookhad & 6 & 2 & 8 & 24.6 \\
& Godad & 13 & 4 & 17 & 33.3 \\
& Tawakal & 20 & 3 & 23 & 30.4 \\
& Talacad & 19 & 2 & 21 & 100.0 \\
\hline \multirow{2}{*}{ Total } & & 58 & 11 & 69 & \\
\hline
\end{tabular}

Table 2. Sex as determinant of Trypanosoma evansi infection in camels.

\begin{tabular}{cccccc}
\hline & & \multicolumn{2}{c}{ Results } & & \\
\cline { 3 - 4 } & & Negative & Positive & & Sero-Prevalence (\%). \\
\hline \multirow{2}{*}{ Sex } & Female & 34 & 8 & 42 & 60.9 \\
& Male & 24 & 3 & 27 & 39.1 \\
\multicolumn{2}{c}{ Total } & 58 & 11 & 69 & 100.0
\end{tabular}

Pearson Chi-Square $=0.379$; Since Chi-Square $\mathrm{X}^{2}=0.379>0.05$ there is no significant difference between the sex and the sero-prevalence.

Tables 3. Sero-prevalence of camel Trypanomiasis on the basis of age.

\begin{tabular}{|c|c|c|c|c|c|}
\hline & & \multicolumn{2}{|c|}{ Results } & \multirow{2}{*}{ Total } & \multirow{2}{*}{ Sero-Prevalence (\%) } \\
\hline & & Negative & Positive & & \\
\hline \multirow{2}{*}{ Age } & $<10$ & 27 & 4 & 31 & 44.9 \\
\hline & $>10$ & 31 & 7 & 38 & 55.1 \\
\hline \multicolumn{2}{|c|}{ Total } & 58 & 11 & 69 & 100.0 \\
\hline
\end{tabular}

Pearson Chi-Square $=0.533$; Since Chi-Square $\mathrm{X}^{2}=0.533<0.05$ there is statistically significant difference in sero-prevalence between age and the sero-prevalence.

Table 4. Sero-prevalence of camel Trypanomiasis on the body condition.

\begin{tabular}{rcccccc}
\hline & & \multicolumn{2}{c}{ Results } & & Total & Sero-Prevalence (\%). \\
\cline { 3 - 4 } & & Negative & Positive & & 76.8 \\
\hline \multirow{2}{*}{ Body conditions } & Poor & 43 & 10 & 53 & 23.2 \\
& Medium & 15 & 1 & 16 & 100.0 \\
\hline
\end{tabular}


study area, 11 (15.9) of camels were positive of which 2 (11.6\%) in Halbookhad, $4(24.6 \%)$ in Godad and 3 (33.3\%) in Tawakal, 2 (30.4\%) in Talacad were recorded.

Generally the highest sero-prevalence of disease was found in Tawakal and the reason could be that the camels in Tawakal have moved from eastern region of Somali Ethiopian. That area is high rate of infection of the trypanosomiasis and its vectors, $33.3 \%$ followed by Talacad $30.4 \%$ as delineated in Table 1 . This result of sero-prevalence (15.9) is in disagreement with the previous study obtained by Abdullahi (2014) who reported 3.2\% and Abdiweli (2013) who reported 2.6\%.

Also the sero-prevalence of the study is higher compared with investigation that was conducted by Ministry of Livestock, Agriculture \& Environment (September 2009) in Galkayo recorded prevalence of 9.4\%.

The possible justification for higher sero-prevalence detected in this study related to season of the study period.

In abroad countries various prevalence was reported by Pacholek et al. [10] (29\%) in Niger, Enwsezor and Sackey [11] (28\%) in Kenya, Al-Rawshed et al. [12] (33\%) in Jordan and Rami et al. [13] (35.4\% and 43.3\%) in Morocco which shows higher prevalence compared to the present study result.

Possible explanation for the lower sero-prevalence rate detected in these studies could be associated with the study period and density of parasite vector in study area.

More reason might be the different sensitivity of different diagnostic techniques used.

The present study reveals higher sero-prevalence infection rate that is noted in females than males as indicated in Table 2. However, the results of this study disagree with the results found by Pathak and Khanna [14] (1993) which reported that all camels were equally susceptible to trypanosome infection regardless of breed and age. Regarding the present study that agrees with other studies in Asia has reported sex related differences in sero-prevalence in camels where females (15.68\%) were observed to be more susceptible to the disease than males (11.76\%) counterparts. The reason could be due to the stress during pregnancy and lactation, which could decrease resistance in female camels and render them more susceptible to T. evansi infection [15]. The age of examined camels determined by interviewing the owners was categorized into two groups according to ages as $(>10)$ adults and young $(<10)$. This study reveals that the higher trypanosome infection sero-prevalence was found to be $(10.1 \%)$ in adult age group $(>10)$ followed by $(5.8 \%)$ in the young age group $(<10)$ as indicated in Table 3. However, there is statistically significant difference in sero-prevalence between age groups where a higher infection rate was recorded in adults camels. The present study agrees with previous result of the Atarhouch et al. [16] who recorded that higher infection rate was in old camels. The higher sero-prevalence infection in adult camels at this period might be due to heavy stress through their use for transportation of goods from one place to another. 


\section{Acknowledgements}

The author would like to express his thanks to Abadir Abdiwahid Jama, Mohamoud Dahir Jama and Abdihakim Mohamoud Farah, for their kindly assistance with blood collection during conduct of the study, and also I would like to thank Dr. Abdinasir Ali, Head of Galkaio Central Veterinary Laboratory for his assistance during the laboratory work.

Finally I would appreciate to Dr. Shafi'I Mohamed Abdullah for his supports to the wire transfer payment procedure.

\section{References}

[1] Moallin, A.S.M. and Heuer, C. (1989) Research Concept on Camel Production and Disease in Central Somalia. Forum on Camel Production, Marketing and Research in the IGADD Sub-Region, 5-7 June 1989.

[2] Hussein, M.A. (1984) Traditional Systems of Camel Management and Husbandry Camel Forum Working Paper No. 7. pp. 27-41.

[3] Njiru, Z.K., Bett, O., Ole-Mapeny, I.M., Githiori, J. and Ndung'u, J.M. (2002) Trypanosomosis and Helminthosis in Camels: Comparison of Ranch and Traditional Camel Management Systems in Kenya. Journal of Camel Research and Practice, 55, 67-71.

[4] Tesfaye, M. (2002) Report of Trypanosome Infection Rate, in G.m.submoristans and G. tachinoides in Didessa Valley from July 29 to September 26/2002, Bedelle.

[5] Uilenberg, G. (1998) A Field Guide for Diagnosis, Treatment and Prevention of African Animal Trypanosomosis. Adapted from the Original Edition by Boyt. W. P. Food and Agriculture Organization of United Nations (FAO), Rome, pp. 43-135.

[6] Urquhart, G.M., Armour, J., Duncan, J.L., Dunn, A.M. and Jennings, F.W. (1996) Veterinary Parasitology. 2nd Edition, Blackwell Science Ltd., London, 212-219.

[7] Reference Kurian, George Thomas (1983)

[8] Visit: http://www.icpac.net

[9] Thrusfield, M. (2005) Veterinary Epidemiology. 2nd Edition, Blackwell Science Ltd., London, 228-247.

[10] Pacholek, X., Gamatic, D., Franek, S.G. and Tibayrene, R. (2001) Prevalence of Trypanosomaevansi Trypanosomosis in Young Camels in West Niger. Revue D'elevage et de Medecine Veterinaire des Pays Tropicaux, 44, 177.

[11] Enwezor, F. and Sackey, A. (2005) Camel Rypanosomosis: A Review. Veterinary Archive, 75, 439-452.

[12] Al-Rawashdeh, O.F., Sharif, L.A., Al-Qudah, K.M. and Al-Ani, F.K. (2003) Trypanosoma evansi Infection in Camels in Jordan. Revue D'elevage et de Medecine Veterinaire des Pays Tropicaux, 20, 233-237.

[13] Rami, M., Atarhouch, T., Bendahman, M.N., Azlaf, R., Kechna, R. and Dakkak, A. (2003) Camels Trypanosomosis in Morocco. A Pilot Disease Control Trial. Veterinary Parasitology, 115, 223-231. https://doi.org/10.1016/S0304-4017(03)00222-X

[14] Pathak, K.M.L. and Khanna, N.D. (1995) Trypanosomiasis in Camel (Camelus dromedarius) with Particular Reference to Indian Sub-Continent: A Review. International Journal of Animal Science, 10, 157-162.

[15] Shah, S.R., Phulan, M.S., Memon, M.A., Rind, R. and Bhatti, W.M. (2004) Trypanosomes Infection in Camels. Pakistan Veterinary Journal, 24, 209-210. 
[16] Atarhouch, T.M., Rami, M., Bendahman, M.N. and Dakkak, N.A. (2003) Camel Trypanosomisis in Morocco1: Results of First Epidemiology Survey. Veterinary Parasitology, 111, 277-286.

Submit or recommend next manuscript to SCIRP and we will provide best service for you:

Accepting pre-submission inquiries through Email, Facebook, LinkedIn, Twitter, etc. A wide selection of journals (inclusive of 9 subjects, more than 200 journals)

Providing 24-hour high-quality service

User-friendly online submission system

Fair and swift peer-review system

Efficient typesetting and proofreading procedure

Display of the result of downloads and visits, as well as the number of cited articles

Maximum dissemination of your research work

Submit your manuscript at: http://papersubmission.scirp.org/

Or contact ojvm@scirp.org 